\title{
ANALYSIS OF THE 11-YEAR RECORD (1987-1997) OF AIR POLLUTION MEASUREMENTS IN ATHENS, GREECE. PART II: PHOTOCHEMICAL AIR POLLUTANTS
}

\author{
P. D. KALABOKAS ${ }^{*}$, \\ L. G. VIRAS', \\ C. C. REPAPIS 1 , \\ J. G. BARTZIS 3
}

${ }^{1}$ Academy of Athens, Research Center for Atmospheric Physics and Climatology, 131, Tritis Septemvriou, str.,11251 Athens, Greece 2Ministry of Environment, Directorate of Air and Noise Pollution Control, 147, Patission str., 11251 Athens, Greece 3National Center of Scientific Research "Demokritos", INT-RP, Environmental Research Laboratory, 15310 Ag. Paraskevi Attikis

*to whom all correspondence should be addressed

\section{ABSTRACT}

This paper deals with the analysis of atmospheric concentrations of secondary photochemical air pollutants in Athens for the 11-year period 1987-1997. Photochemical pollution, which seems to be the most serious air pollution problem in Athens, is originating mainly from the transformation of car emissions, and its control is a quite complicated task since various non-linear phenomena are implicated. The main subject of this work is to examine whether the substantial decrease observed in the concentrations of the primary air pollutants, especially for $\mathrm{CO}$, in Athens in recent years is followed by a corresponding decrease in the photochemical air pollutant levels in the Athens basin, while the characteristics of the seasonal and diurnal profiles of photochemical pollution are investigated. In this context, the interannual variability of $\mathrm{O}_{3}$ and $\mathrm{O}_{\mathrm{X}}\left(\mathrm{O}_{3}+\mathrm{NO}_{2}\right)$ is examined for the peripheral stations of Liossia (10 km northwest from city center) and Smyrni (5 km southeast), which have continuous records of $\mathrm{O}_{3}$ and $\mathrm{NO}_{2}$ data since 1987. In general, the concentrations of the photochemical pollutants (especially $\mathrm{O}_{\mathrm{X}}$ ) in both examined stations are comparable, while they seem to have remained essentially at the same levels since 1990 . Further pollution abatement measures should be taken in order to comply with the EU ozone air pollution standards in the Athens basin.

KEY WORDS: Air pollution; Photochemical oxidants; Tropospheric ozone; Athens

\section{INTRODUCTION}

Atmospheric pollution in Athens, Greece, has been the subject of many studies from national and international research groups during the past decade so that its most important characteristics are already known (Lalas et al., 1987; Mantis et al., 1992; Viras and Siskos, 1992; Kallos et al., 1993; Kassomenos et al., 1995; Ziomas et al.,
1995; Ziomas et al., 1998, among others). The main factors contributing to the creation of the Athenian smog or "nephos" as it is called in Greek, are mentioned in the introduction of the previous paper (Kalabokas et al., 1999). According to the measurements of the local air pollution monitoring network during the recent 
years, the most serious problems of compliance with air pollution standards are due to the secondary formation of photochemical pollutants, like the continuously monitored $\mathrm{O}_{3}$ and $\mathrm{NO}_{2}$, and not to the primary ones (MinEnv report, 1998).

The most characteristic photochemical pollutant among those monitored is ozone. Ozone plays an important role in the physicochemical processes in the boundary layer and the free troposphere. Ozone is the main precursor of the hydroxyl radical $\mathrm{OH}$, which is the strongest oxidant of atmospheric species and the agent most responsible for the initiation of the chain reactions leading to the oxidation of hydrocarbons (Finlayson-Pitts and Pitts, 1986). At the same time, ozone is also a strong oxidant by itself. At certain concentration levels, which may be reached relatively frequently in many urban areas around the world but also in rural areas close to the urban centers, ozone may cause damages to humans, animals and vegetation (Bates, 1994).

The air pollution monitoring network of the Greater Athens area consists of 10 stations. The selection of the stations of Liossia and Smyrni (see Fig. 1 of the previous work, Kalabokas et al., 1999) for the study of the photochemical activity in the basin was made primarily on the basis that the highest ozone concentrations are observed in the periphery of the urban area and not in its center like the primary pollutants (Amanatidis et al., 1993; Kalabokas et al., 1995, Kalabokas and Bartzis, 1998), which is in agreement with observations made in other urban areas worldwide (Finlayson-Pitts and Pitts, 1986). These two stations have the longest observation record since 1987, when regular $\mathrm{O}_{3}$ measurements started, in comparison to the other peripheral stations in the network. Their respective locations give also a representative picture of the urban area since they cover two opposite sections (NW and SE). In addition, the ozone levels at Liossia are generally the highest of all stations, and therefore this station is considered as the most characteristic of the network regarding photochemical pollution (MinEnv report, 1998).

The basic reasons for the high ozone levels at Liossia are the following:

a) the photochemical pollution episodes are most frequently taking place when southern winds are prevailing (usually associated with the build-up of sea-breeze), and in this case the sta- tion is downwind of the urban center.

b) The lower emissions of nitrogen oxide at the site relatively to the city-center destroy less ozone especially during the night.

c) The background ozone levels are important in the periphery of the basin and they are added to the ozone produced downwind of the urban area in the peripheral stations (Kalabokas et al., 1996; Kourtidis et al., 1996; Millan et al., 1997; Viglas et al., 1998)

Due to the health hazards caused to the population by the presence of $\mathrm{O}_{3}$ in the atmosphere, air quality standards are set by different countries or international organizations. The current standards adopted by the EU, which are also applied in Greece, are:

a) $360 \mu \mathrm{g} \mathrm{m}^{-3}, 1$ hour average, alert level.

b) $180 \mu \mathrm{g} \mathrm{m}^{-3}, 1$ hour average, population warning level.

c) $110 \mu \mathrm{g} \mathrm{m}^{-3}, 8$ hour average, threshold for human health protection (EU Directive 92/72/EEC).

The parallel examination of the variation of $\mathrm{O}_{3}$ and $\mathrm{NO}_{2}$ concentration levels is necessary due to the fast destruction of $\mathrm{O}_{3}$ in the presence of $\mathrm{NO}$ with subsequent $\mathrm{NO}_{2}$ production. For this purpose, the quantity $\mathrm{O}_{\mathrm{X}}=\mathrm{NO}_{2}+\mathrm{O}_{3}$ (called "potential $\mathrm{O}_{3}$ ") is also examined as it is more appropriate to assess photooxidant ozone levels instead of ozone alone (Kley et al., 1994).

\section{RESULTS AND DISCUSSION}

As it was shown in the previous paper (Kalabokas et al., 1999), the atmospheric concentrations of primary pollutants linked to automobile traffic (especially $\mathrm{CO}$ ) have been decreasing in the city-center after 1990. The CO concentrations dropped sharply in 1991-1992, which coincides with the period of the replacement of old technology cars suggesting that this measure has been successful in reducing significantly primary automobile emissions.

As a first approach in the study of photochemical air pollution levels, figure 1 presents the $\mathrm{O}_{3}$ interannual variation in the form of 12 -month running mean curves for the stations of Smyrni and Liossia based on mean monthly values. In general, Liossia shows always greater values than Smyrni. Before 1991 the difference was significant and the values at Liossia were almost double than those at Smyrni. After 1991 the gap narrowed and the val- 


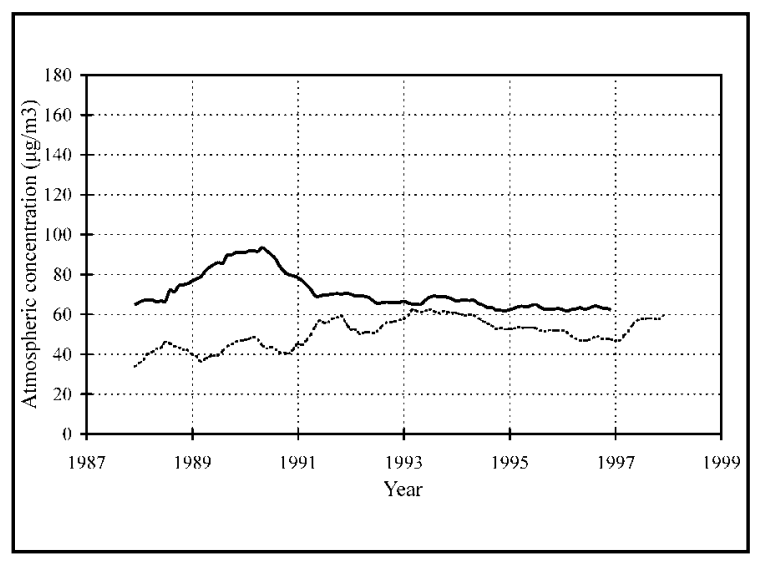

Figure 1. Interannual variations of $\mathrm{O}_{3}$ concentrations in Athens in the peripheral stations of Liossia and Smyrni (12-month running averages)

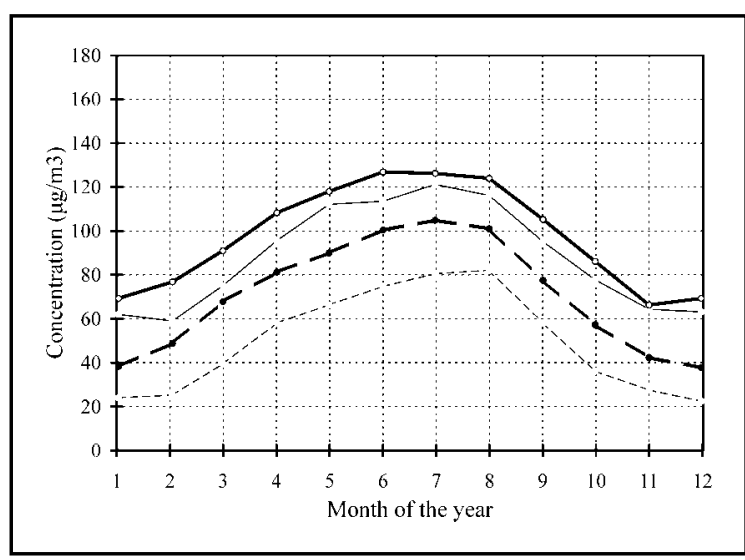

Figure 2. Seasonal variation of $\mathrm{O}_{3}$ (dashed lines) and $\mathrm{O}_{\mathrm{X}}$ (solid lines), at Liossia (bold lines) and Smyrni for 1987-1996

ues stabilized around $65 \mu \mathrm{g} \mathrm{m}^{-3}$ for Liossia and 55 $\mu \mathrm{g} \mathrm{m}^{-3}$ for Smyrni. Considering Smyrni, an upward trend is observed between 1987 and 1992 with an increase in the $\mathrm{O}_{3}$ values of about $50 \%$, while at Liossia, except for the high values in 1989 and 1990, the $\mathrm{O}_{3}$ levels remained almost constant. It comes out from this figure that after 1990, no characteristic change of $\mathrm{O}_{3}$ concentration levels similar to that observed for $\mathrm{CO}$ is found.

Ozone, due to its photochemical nature, shows a strong seasonal dependence following the variations of solar irradiation. Figure 2 presents the seasonal variation of $\mathrm{O}_{3}$ and $\mathrm{O}_{\mathrm{X}}$ in the peripheral sta-

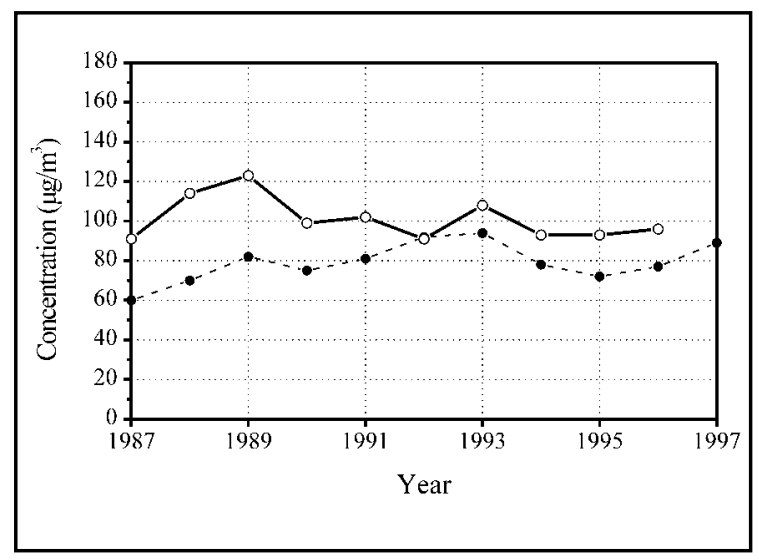

Figure 3. Interannual variations of average summer $\mathrm{O}_{3}$ concentrations at Liossia (bold solid line) and Smyrni (dashed line)

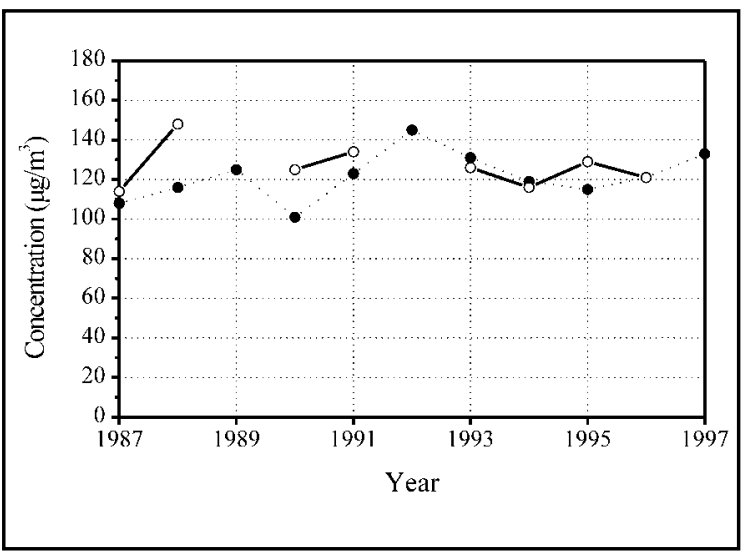

Figure 4. Interannual variations of average summer $\mathrm{O}_{\mathrm{X}}$ concentrations in Liossia (bold solid line) and Smyrni (dashed line). (Missing $\mathrm{NO}_{\mathrm{X}}$ data at Liossia)

tions of Liossia and Smyrni. A strong seasonal variation for both stations with a characteristic summer maximum is observed. The summer average ozone concentrations in both stations are higher than the winter levels by a factor of three, which becomes a factor of two if $\mathrm{O}_{\mathrm{X}}\left(\mathrm{O}_{3}+\mathrm{NO}_{2}\right)$ is considered. The summer ozone levels are by $25 \%$ higher at Liossia than at Smyrni but the difference for the summer $\mathrm{O}_{\mathrm{X}}$ levels in these two stations is only about $5 \%$. This is an indication that the average $\mathrm{O}_{\mathrm{X}}$ levels in the entire Athens basin should be quite similar since these stations are located in diametrically opposite sites. 
Since photochemical activity during summer months is much more important than for the rest of the year, the interannual variation of average summer (June, July, August) $\mathrm{O}_{3}$ concentrations of both stations is examined separately (Fig. 3). It comes out that no substancial change exists with the general trend presented in figure 1. At Liossia the average summer values are close to the level of $100 \mu \mathrm{g} \mathrm{m}^{-3}$, while at Smyrni they vary around 80 $\mu \mathrm{g} \mathrm{m}^{-3}$. At Smyrni an almost constant increase between 1987 and 1992 is observed. If the respective $\mathrm{O}_{\mathrm{X}}$ interannual variation is plotted (see Fig. 4 ), the levels at both stations are approaching each other, and in general they remained constant throughout the whole period 1987-1997, in the

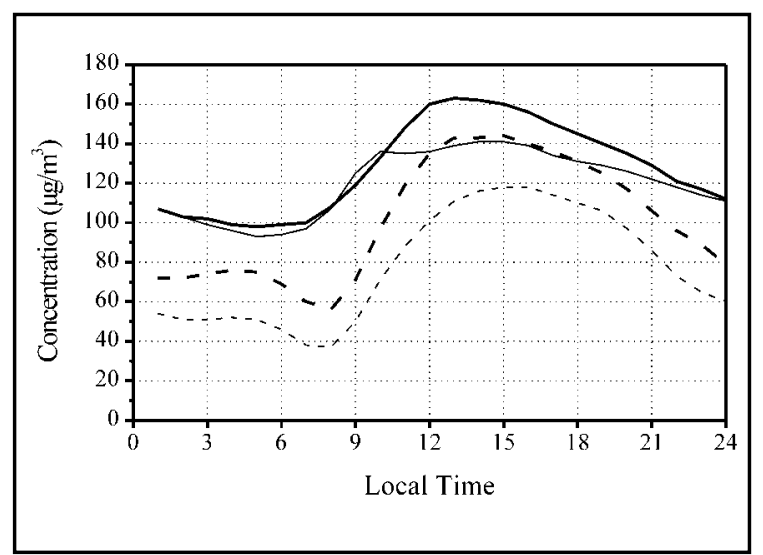

Figure 5. Diurnal summer variation of $\mathrm{O}_{3}$ dashed lines) and $\mathrm{O}_{\mathrm{X}}$ (solid lines), at Liossia (bold lines) and Smyrni for 1987-1996

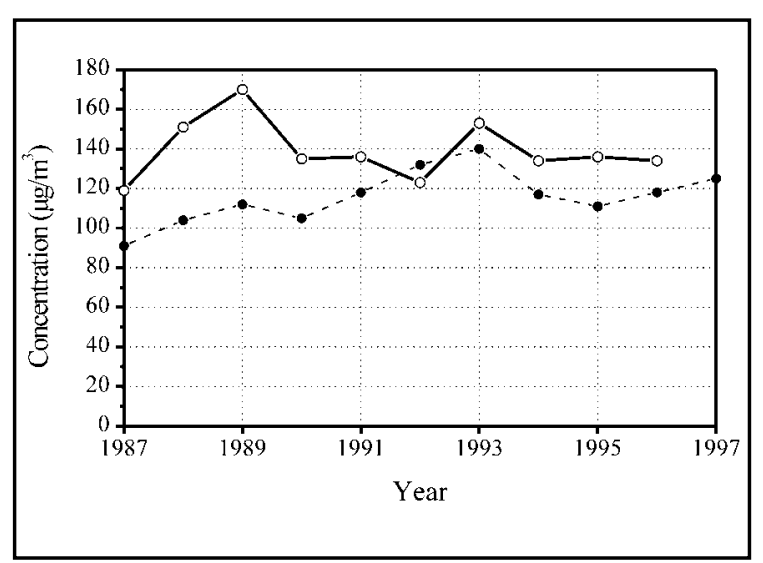

Figure 6. Interannual variations of summer afternoon (12-18 hours) $\mathrm{O}_{3}$ concentrations at Liossia (bold solid line) and Smyrni (dashed line) range of $120-130 \mu \mathrm{g} \mathrm{m}^{-3}$.

Apart from marked seasonal variation, ozone exhibits also a strong diurnal variation with a maximum at noon and afternoon hours. The summer diurnal variation of $\mathrm{O}_{3}$ and $\mathrm{O}_{\mathrm{X}}$ in both peripheral stations of Athens is shown in figure 5. The daily maximum ozone value at Liossia is observed between 13 and 14 hours, while at Smyrni between 15 and 16 hours. The maximum value is about 2-2.5 times higher than the nocturnal levels for both stations. The difference between the two stations takes its maximum value between 12 and 13 hours. During the night and the early morning hours, the $\mathrm{O}_{\mathrm{X}}$ values are similar, but during the rest of the day-time hours Liossia shows always

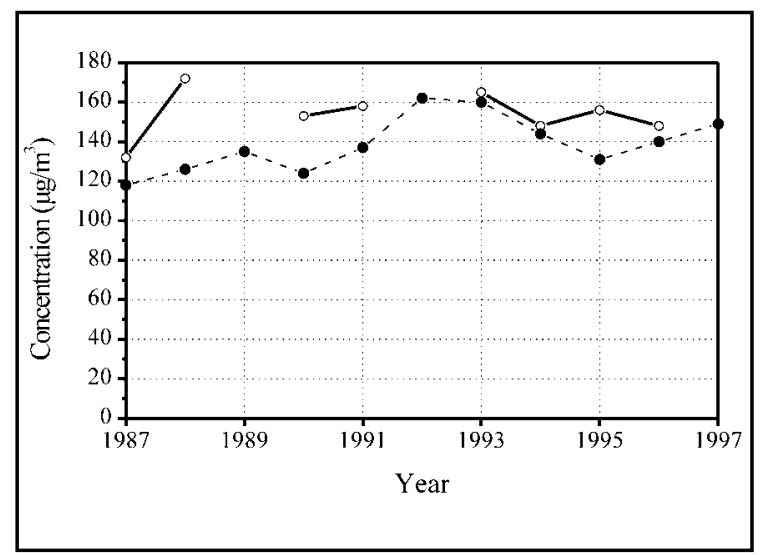

Figure 7. Interannual variations of summer afternoon (12-18 hours) $\mathrm{O}_{\mathrm{X}}$ concentrations at Liossia (bold solid line) and Smyrni (dashed line). (Missing $\mathrm{NO}_{\mathrm{X}}$ data at Liossia)

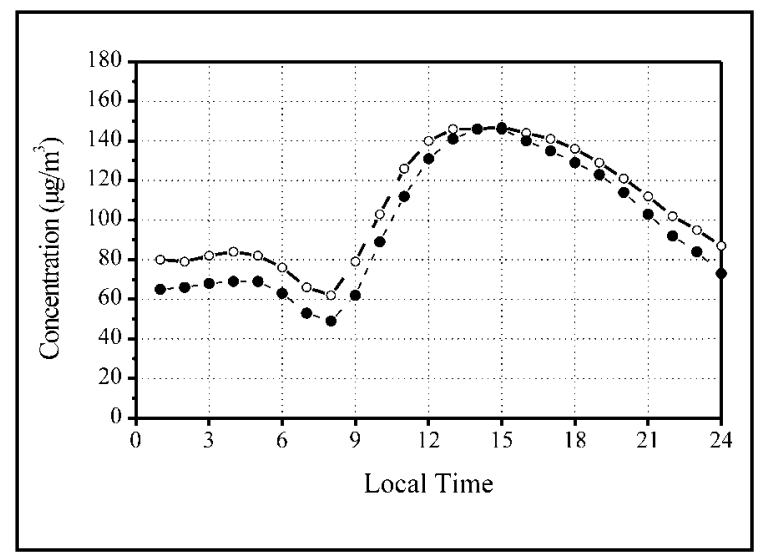

Figure 8. Average diurnal summer variation of $\mathrm{O}_{3}$ at Liossia for the periods 1987-1990 (solid line) and 1993-1996 (dashed line) 
higher values reflecting the higher photochemical activity taking place at this site.

Since the most important ozone concentrations are recorded in summertime in the afternoon hours (12 to 18), an examination of the variation of the average levels during this period of the day is performed showing the maximum $\mathrm{O}_{3}$ levels (Fig. 6). It comes out that the curves show a similar pattern with the average summer ones (Fig. 3) but their respective levels are significantly higher (at $140 \mu \mathrm{g} \mathrm{m} \mathrm{m}^{-3}$ for Liossia and $120 \mu \mathrm{g} \mathrm{m} \mathrm{m}^{-3}$ for Smyrni). These levels are considered high in comparison to the existing standard of $110 \mu \mathrm{g} \mathrm{m}^{-3}$ for human health protection (EU Directive 92/72/EEC). The corresponding figures for $\mathrm{O}_{\mathrm{X}}$ show again that the levels remained quite-stable, especially after 1990-1991, and that the photo-oxidant values between the two stations are close to each other (Fig. 7).

In order to examine whether the diurnal course of ozone photochemical production has changed in both stations before and after the replacement of old technology cars, the average summer diurnal variation of $\mathrm{O}_{3}$ at Liossia for the 4-year periods 1987-1990 and 1993-1996 is presented in figure 8. In general, the $\mathrm{O}_{3}$ diurnal variation for both periods has not changed significantly during the daytime hours, but it is slightly lowered during the night in the period 1993-1996. Another difference is that the hour when the daily maximum is recorded is shifted two hours later during the day in the period 1993-1996, reflecting some changes in the diurnal photochemical cycle. The same characteristics for the station at Smyrni are examined in figure 9, where it is clear that in the second period, 1993-1996, after the replacement of old technology cars, the photochemical activity in the site is enhanced up to $15 \%$ taking also its maximum value between 15 and 16 h, two hours later than during the first period.

In order to make a first screening for the detection of the relative influence of possible factors determining the above described ozone behaviour, some key meteorological and emission parameters were examined. Figures 10 and 11 present the monthly summer average sunshine duration as well as the corresponding relative frequency of northern/southern winds, respectively (data of the National Observatory of Athens). The importance of this parameter is discussed in the previous work (Kalabokas et al., 1999). If these curves are exam- ined in parallel with the corresponding ones for ozone and $\mathrm{O}_{\mathrm{X}}$ (Figs. 3 and 4), no straightforward connections in the variations of the summer average values can be established. It comes out that the variations of these meteorological parameters do not determine the variation of the ozone levels, except probably in the rare case of summer 1992, when more southern winds than northern winds were observed. It has to be mentioned though that concerning sunshine duration, summers in Athens are quite uniform since the variations of this parameter are quite small, always less than $10 \%$ from year to year.

As far as the evolution of urban emissions of air pollutants is concerned, it should be noted that the ozone producing substances, nitrogen oxides and hydrocarbons, are both emitted mainly from traffic (by about 3/4 in the warm period of the year). For both pollutants, the gasoline-powered private car fleet is the most important source of pollution (Katsoulis, 1996; MinEnv report, 1989). There is a rapid evolution in the number of private cars in Athens (MinEnv report, 1998b) and a steady increasing rate with a $50 \%$ increase in total car number recorded in the last 8 years (1989-1997). The new registered cars, after 1989 , were all equipped with a catalyst, but in 1997 the old technology cars were still the majority. The increase in car number is not followed by a comparable increase in the ozone precursor concentrations due to the presence of the catalysts. The hydrocarbons are expected to increase less than $\mathrm{NO}_{\mathrm{X}}$ because the 3-way catalyst is much more efficient for them. The emissions of a vehicle equipped with a catalyst type EC 94/12 are 30 times less than the emissions of a corresponding conventional vehicle, while the $\mathrm{NO}_{\mathrm{X}}$ emissions of a catalytic car are 6 times less (Samaras et al., 1997). Due to the presence of the catalyst in all new registered passanger cars and the stabilization of the number of conventional cars after 1992, it is expected that the most important contributor to the hydrocarbon emissions in the atmosphere of the Greater Athens area are still the conventional passenger cars, while they hold also an important share in the $\mathrm{NO}_{\mathrm{X}}$ emissions. Their relative importance is expected to increase due to the improvements in the performance of the new catalyst types (Samaras et al., 1997).

However, the linking of the emission and meteorological factors to the concentrations of 


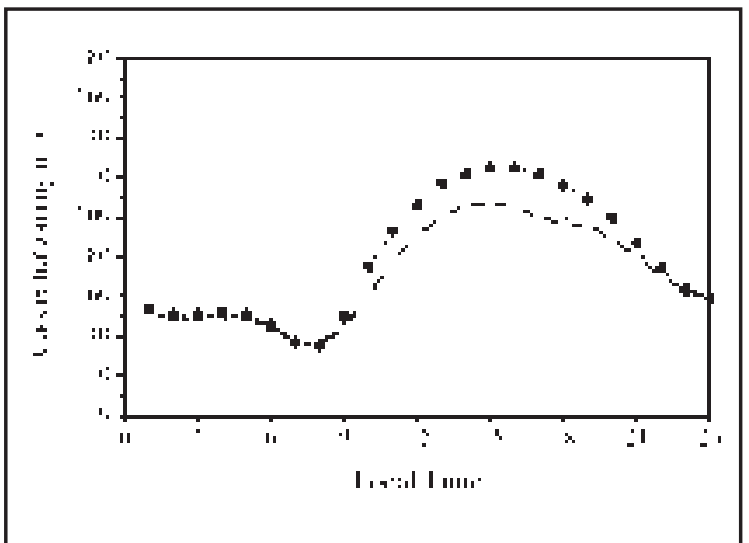

Figure 9. Average diurnal summer variation of $\mathrm{O}_{3}$ at Smyrni for the periods 1987-1990 (solid line) and 1993-1996 (dashed line)

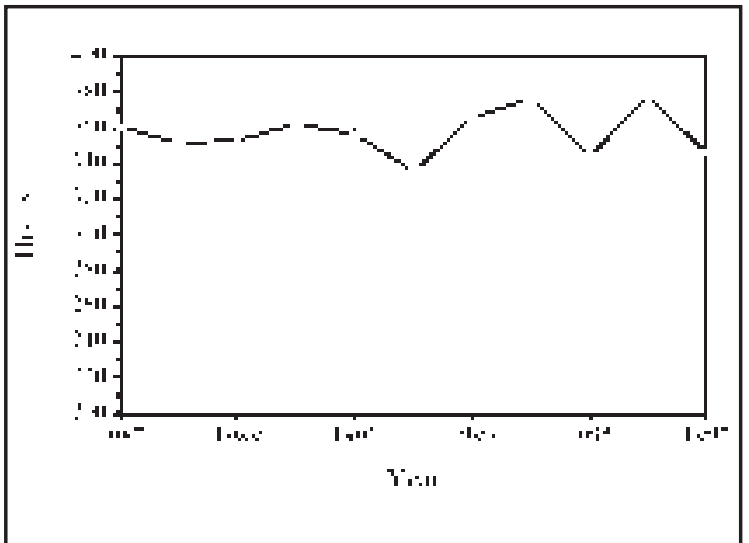

Figure 10. Interannual variation of the monthly summer average sunshine duration in Athens

$\mathrm{O}_{3}$ and other photochemical oxidants in an urban area like the Greater Athens area is not straightforward, when broad climatological averages are examined. This is due to the high complexity of the chemistry as well as of the meteorology involved in the tropospheric ozone formation in urban plumes (Kley, 1997). A very critical point in this subject is the existing ratio $\mathrm{NO}_{\mathrm{X}} / \mathrm{VOC}$. For example, decreasing $\mathrm{NO}_{\mathrm{X}}$ can actually lead to an increase in $\mathrm{O}_{3}$ at high $\mathrm{NO}_{\mathrm{X}} / \mathrm{VOC}$ ratios, and in this VOC-limited regime control of organic compounds is most effective (Finlayson-Pitts and Pitts, 1997). On the other hand, at low $\mathrm{NO}_{\mathrm{X}} / \mathrm{VOC}$ ratios the chemistry becomes $\mathrm{NO}_{\mathrm{X}}$-limited. The

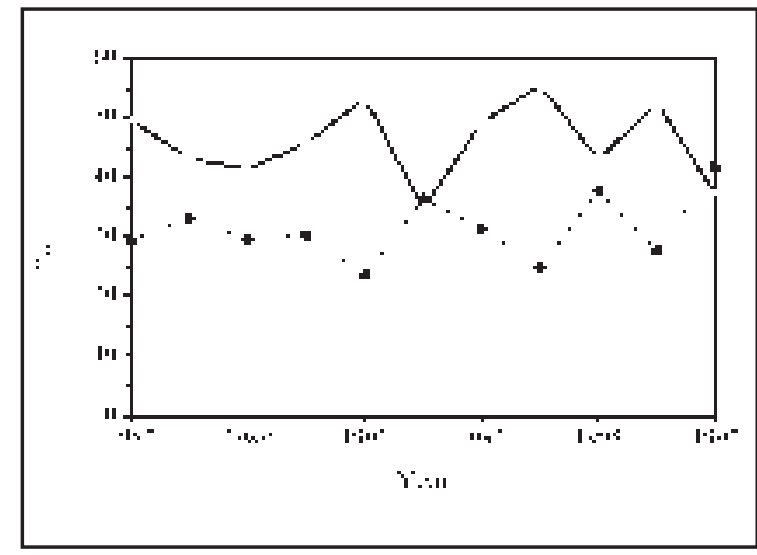

Figure 11. Interannual variation of the monthly summer average frequency of appearance of northern (solid line) and southern (dashed line) winds in Athens

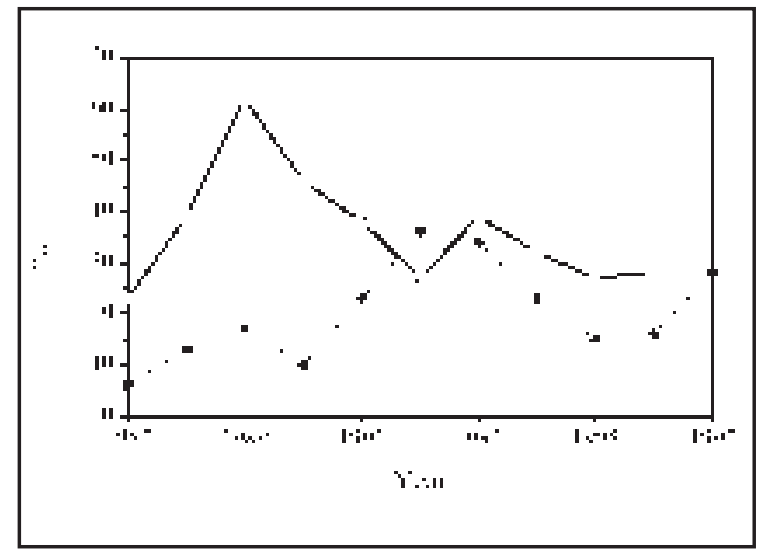

Figure 12. Percentage of days in a year exceeding the $110 \mu \mathrm{g} / \mathrm{m}^{3}$ 8-hour average $(12-20 \mathrm{~h})$ standard at Liossia (bold solid line) and Smyrni (dashed line)

issue becomes even more complicated when examining an air mass traveling over an urban area, because the chemistry tends to change from a VOC-limited regime to a $\mathrm{NO}_{\mathrm{X}}$-limited as the air mass moves downwind from an urban center. This is because the $\mathrm{NO}_{\mathrm{X}}$ sources are larger in urban areas but at the same time $\mathrm{NO}_{\mathrm{X}}$ is easier removed from an air mass as it travels downwind. VOCs do not decrease so rapidly because of widespread emissions of biogenic compounds as well as less efficient deposition (Finlayson-Pitts and Pitts, 1997).

In Athens, the examination of the interannual variations of the above mentioned ratio $\mathrm{NO}_{\mathrm{x}} /$ 
VOC and the way it was affected from the replacement of old technology cars is not possible to be done. This is because hydrocarbons have not been measured systematically so far by the air pollution network. Only some short-term measurements from intensive air pollution campaigns exist, which show that reducing the VOCs is more effective in controlling ozone (Rappengluck et al., 1998; Ziomas et al., 1998). The first continuous measurements are expected to start by the end of 1999.

Finally, figure 12 presents the percentage of days in a year exceeding the $110 \mu \mathrm{g} \mathrm{m}^{-3}$ 8-hour average (12-20 h) at both stations. In general, it can be stated that the standard for human health protection (110 $\mu \mathrm{g} \mathrm{m}^{-3}, 8-\mathrm{h}$ average) is frequently exceeded at both stations, especially at Liossia, where after 1991 exceedances occur as an average in $1 / 3$ of the days in a year, which cover almost the entire summer season. This means that in Athens still exists a serious problem of population exposure to atmospheric pollution due to ozone for its four million inhabitants. Therefore, ozone precursor emissions should be absolutely reduced. The problem becomes quite complicated if it is recalled that the rural ozone levels close to the urban area of Athens but also in other parts of Greece are already high, approaching the limit of $110 \mu \mathrm{g} \mathrm{m}^{-3}$ (Kalabokas et al., 1996; Kourtidis et al., 1996; Viglas et al., 1998). Therefore, in order to comply with this standard, very substantial reductions of automobile emissions should be achieved with a priority on VOC control (Ziomas et al., 1998).

\section{CONCLUSIONS}

The two peripheral stations with the longest $\mathrm{O}_{3}$ record in the Athens basin (Liossia, $10 \mathrm{~km} \mathrm{NW}$ from the city center and Smyrni, $5 \mathrm{~km} \mathrm{SE}$ ) do not show any characteristic change in $\mathrm{O}_{3}$ concentrations during the 1990-1992 period (restriction in traffic emissions) and their levels remained constant until 1997.
The summer average ozone concentrations in both stations are higher than the winter levels by a factor of three (or a factor of two if $\mathrm{O}_{\mathrm{X}}=\mathrm{O}_{3}+\mathrm{NO}_{2}$ is considered).

The average ozone summer concentrations do not significantly change after 1990-1991 in both stations. In this period the ozone levels at Liossia are by about $20 \%$ higher than at Smyrni but the average summer $\mathrm{O}_{\mathrm{X}}$ concentrations in both stations are quite similar.

The maximum diurnal ozone value at Liossia is observed at 13-14 hours, while at Smyrni two hours later. The maximum value is about 2-2.5 times higher than the nocturnal levels for both stations.

The ozone at Liossia in the summer afternoon 6 hours span (12-18) is on the average about $10-15 \%$ higher than at Smyrni. An increasing trend is observed for Smyrni in the first half of the period, while for Liossia the levels remain the same after 1990.

The summer diurnal photochemical ozone production at Smyrni in the 4 years 1993-1996 has been increased at all hours during the day up to about $15 \%$ in comparison to the 4 years 1987 1990, while at Liossia no significant change of this kind was found.

The standard for human health protection (110 $\mu \mathrm{g} \mathrm{m} \mathrm{m}^{-3}, 8$-h average) is frequently exceeded at both stations, especially at Liossia, where after 1991 exceedances occur in $1 / 3$ of the days in a year, which cover almost the entire summer season.

As a general conclusion it can be stated that while in the central stations the primary pollutants linked with automobile traffic have shown a clear decrease following the measures for pollution abatement of the period 1990-1992, the photochemical pollution in the Athens basin remains essentially at the same levels for the years following 1990. Further pollution abatement measures should be taken in order to comply with the EU ozone air pollution standards in the Athens basin.

\section{BIBLIOGRAPHY}

Amanatidis G., Fotopoulos A., Viras L. and Bartzis J.G. (1993). Ozone concentration levels in the Athens basin (in Greek). Proceedings of the 3rd Conference of Environmental Science and Technology, Vol I, pp. 428-437, Molyvos, Lesbos, Greece

Bates D. (1994). The effects of ozone on plants and people. In: Chemistry of the Atmosphere: Its Impact on Global Change, edited by J. Calvert, 239-244, Blackwell Scientific Publications

EU Directive 92/72/ECC. Official Journal of the European Communities No L 297/1

Finlayson-Pitts B. and Pitts J. Jr. (1986). Atmospheric Chemistry: Fundamentals and Experimental Techniques. J. Wiley, New York 
Finlayson-Pitts B. and Pitts J. Jr. (1997). Tropospheric air pollution: Ozone, Airborne toxics, Polycyclic Aromatic Hydrocarbons, and Particles. Science, 276, 1045-1051

Kalabokas P., Viras L., Fotopoulos A., and Bartzis J.G. (1995). A study of the variations of ozone concentration levels in the periphery of the Athens basin (in Greek). Proceedings of the 4th Conference of Environmental Science and Technology, Vol I, 510-525, Molyvos, Lesbos, Greece

Kalabokas P., G. Amanatidis and J. Bartzis (1996). Rural ozone levels at an Eastern Mediterranean site (Attica, Greece). Proceedings of the XVIII Quadrennial Ozone Symposium Edited by R. Bojkov and G. Visconti, 379-382, L' Aquila, Italy

Kalabokas P. and Bartzis J. (1998). Photochemical air pollution characteristics at the station of the NCSRDemokritos, during the MEDCAPHOT-TRACE campaign, Greece (August 20th-September 20th, 1994). Atmos. Environ., 32, 2123-2140.

Kalabokas P., L. G. Viras, C. C. Repapis (1999). Analysis of the 11-year record (1987-1997) of air pollution measurements in Athens, Greece. Part I: Primary air pollutants. Global Nest: The International Journal, 1, 157-167

Kallos G., P. Kassomenos and Pielke R.A. (1993). Synoptic and mesoscale weather conditions during air pollution episodes in Athens, Greece. Bound. Layer Meteorol., 62, 163-184

Kassomenos P., V. Kotroni and G. Kallos (1995). Analysis of climatological and air quality observations from Greater Athens area. Atmos. Environ., 29, 3671-3688

Kley D., Geiss H., and Mohnen V. (1994). Tropospheric ozone at elevated sites and precursor emissions in the United States and Europe. Atmos. Environ., 28, 149-158.

Kley D. (1997). Tropospheric chemistry and tranport. Science, 276, 1043-1044

Kourtidis K., I. Ziomas, C. Zerefos, D. Balis, P. Suppan, A. Vassaras, V. Kosmidis and A. Kentrarchos (1996). On the background ozone values in Greece. 7th European Symposium on Physico-chemical Behaviour of Atmospheric Pollutants: The oxidizing capacity of the Troposphere, EUR 17482 EN, 456-461, Venice, Italy

Lalas D., M. Tombrou-Tsella, M. Petrakis, D. Asimakopoulos and C. Helmis (1987). An experimental study of the horizontal and vertical ozone distribution over Athens. Atmos. Environ., 21, 2681-2693

Mantis O., C. Repapis, C. Zerefos and J. Ziomas (1992) Assessment of the potential for photochemical air pollution in Athens: A comparison of emissions and air pollutants in Athens with those in Los Angeles. $J$. Appl. Met., 31, 1467-1476

MinEnv report (1989). Atmospheric pollution in the Athens area. Technical report.Vol. 2. Pollution sources. Directorate of air pollution and noise control, Ministry of Environment (in Greek)

MinEnv report (1998). Atmospheric pollution in Athens - 1997. Directorate of air pollution and noise control, Ministry of Environment (in Greek)

MinEnv report (1998b). "Attiki-SOS. Atmospheric pollution in Athens, 1994-1997". Ministry of Environment (in Greek)

Millan M., R. Salvador, E. Mantilla and G. Kallos (1997). Photooxidant dynamics in the Mediterrannean basin in summer: Results from European research projects. J. Geoph. Res., 102, D7, 8811-8823

Rappengluck, B. P. Fabian, P. Kalabokas, L. Viras, I. Ziomas (1998). Volatile organic compounds and their contribution to the enhancement of photooxidants in the Greater Athens area under Mediterranean climate conditions. Atmos. Environ., 32, 2103-2122.

Repapis C. C., Zerefos C.S. and Tritakis B. (1975). On the Etesians over the Aegean. Proc. Acad. Athens, 52, 572-606.

Samaras Z., Andrias A., Zachariadis T. and Aslanoglou M. (1997). Forecast of road traffic emissions for the Greater Athens area. Proceedings of the International Scientific Workshop Athens 2004 Air Quality Study, 39-50, Athens, Greece

Viras L. and P. Siskos (1992). Air pollution by gaseous pollutants in Athens, Greece. In: Gaseous pollutants: Characterization and Cycling, Edited by J.O. Nriagu, J. Wiley, 271-305

Viglas P., Gogousos O. and Viras L. (1998). Ozone measurements in a rural area (Aliartos) (in Greek). Proceedings of the 4th Hellenic Conference on: Meteorology, Climatology and Physics of the Atmosphere, 3, 405-411, Athens

Ziomas I., P. Suppan, B. Rappengluck, D. Balis P. Tzoumaka, D. Melas, A. Papayiannis, P. Fabian and C. Zerefos, (1995). A contribution to the study of photochemical smog in the Greater Athens area. Beitr. Phys. Atmosph. 68, 191-203

Ziomas I. C. Tzoumaka B., Balis D., Melas D., Zerefos C., S., and Klemm O. (1998). Ozone episodes in Athens, Greece. A modelling approach using data from the MEDCAPHOT-TRACE, Atmos. Environ., 32 , 2313-2322 